\title{
Potentially Detrimental Effects of Hyperosmolality in Patients Treated for Traumatic Brain Injury
}

\author{
Wojciech Dabrowski ${ }^{1, *,+} \mathbb{D}$, Dorota Siwicka-Gieroba ${ }^{1, *,+} \mathbb{D}$, Chiara Robba ${ }^{2}$, Magdalena Bielacz ${ }^{3}$, \\ Joanna Sołek-Pastuszka ${ }^{4}$, Katarzyna Kotfis ${ }^{5}$ (D), Romuald Bohatyrewicz ${ }^{4}{ }^{(D)}$, Andrzej Jaroszyński ${ }^{6}$, \\ Manu L. N. G. Malbrain $1,7,8$ (D) and Rafael Badenes 9 (D)
}

check for updates

Citation: Dabrowski, W.; SiwickaGieroba, D.; Robba, C.; Bielacz, M.; Sołek-Pastuszka, J.; Kotfis, K.; Bohatyrewicz, R.; Jaroszyński, A.; Malbrain, M.L.N.G.; Badenes, R. Potentially Detrimental Effects of Hyperosmolality in Patients Treated for Traumatic Brain Injury. J. Clin. Med. 2021, 10, 4141. https:// doi.org/10.3390/jcm10184141

Academic Editor: Kenji Dohi

Received: 31 May 2021

Accepted: 7 September 2021

Published: 14 September 2021

Publisher's Note: MDPI stays neutral with regard to jurisdictional claims in published maps and institutional affiliations.

Copyright: (c) 2021 by the authors. Licensee MDPI, Basel, Switzerland. This article is an open access article distributed under the terms and conditions of the Creative Commons Attribution (CC BY) license (https:/ / creativecommons.org/licenses/by/ $4.0 /)$.
1 Department of Anaesthesiology and Intensive Care, Medical University of Lublin, 20-954 Lublin, Poland; manu.malbrain@umlub.pl

2 Department of Anaesthesia and Intensive Care, Policlinico San Martino, 16100 Genova, Italy; kiarobba@gmail.com

3 Institute of Tourism and Recreation, State Vocational College of Szymon Szymonowicz, 22-400 Zamosc, Poland; magda.bielacz@gmail.com

4 Department of Anaesthesiology and Intensive Care, Pomeranian Medical University, 71-252 Szczecin, Poland; pastuszka@mp.pl (J.S.-P.); romuald.bohatyrewicz@pum.edu.pl (R.B.)

5 Department of Anaesthesiology, Intensive Therapy and Acute Intoxications, Pomeranian Medical University, 70-111 Szczecin, Poland; katarzyna.kotfis@pum.edu.pl

6 Department of Nephrology, Institute of Medical Science, Jan Kochanowski University of Kielce, 25-736 Kielce, Poland; jaroszynskiaj@interia.pl

7 International Fluid Academy, Dreef 3, 3360 Lovenjoel, Belgium

8 Medical Department, AZ Jan Palfjin Hospital, Watersportlaan 5, 9000 Gent, Belgium

9 Department of Anaesthesiology and Intensive Care, Hospital Clìnico Universitario de Valencia, University of Valencia, 46010 Valencia, Spain; rafaelbadenes@gmail.com

* Correspondence: w.dabrowski5@yahoo.com (W.D.); dsiw@wp.pl (D.S.-G.)

$\dagger$ Wojciech Dabrowski and Dorota Siwicka-Gieroba contributed equally to this article.

Abstract: Hyperosmotic therapy is commonly used to treat intracranial hypertension in traumatic brain injury patients. Unfortunately, hyperosmolality also affects other organs. An increase in plasma osmolality may impair kidney, cardiac, and immune function, and increase blood-brain barrier permeability. These effects are related not only to the type of hyperosmotic agents, but also to the level of hyperosmolality. The commonly recommended osmolality of $320 \mathrm{mOsm} / \mathrm{kg} \mathrm{H}_{2} \mathrm{O}$ seems to be the maximum level, although an increase in plasma osmolality above $310 \mathrm{mOsm} / \mathrm{kg} \mathrm{H}_{2} \mathrm{O}$ may already induce cardiac and immune system disorders. The present review focuses on the adverse effects of hyperosmolality on the function of various organs.

Keywords: osmolality; traumatic brain injury (TBI); hypertonic saline; mannitol; osmolar gap

\section{Introduction}

Hyperosmotic therapy has been recommended for treatment of cerebral edema (CE) and increased intracranial pressure (ICP) in patients with traumatic brain injury (TBI) and other cerebral diseases [1,2]. The main purpose of increasing the plasma osmolality is to force the shift of water from the brain to the vascular space through the blood-brain barrier (BBB) [2]. According to the Monroe-Kellie doctrine, the sum of the volumes of intracerebral blood, cerebrospinal fluid (CSF), and brain is constant, therefore a decrease of water from the interstitial space of the brain reduces cerebral volume and cerebral edema, which may improve cerebral perfusion [3,4]. Experimental studies have also documented that hyperosmolar therapy attenuates trauma-related inflammatory response by reducing neutrophil activation and neutrophil-endothelium binding [5,6]. Currently, mannitol and hypertonic saline (HTS) have only been recommended for the treatment of intracranial hypertension $(\mathrm{ICH})$ and cerebral edema, and the final goal of hyperosmotic therapy is the achievement of plasma osmolality not higher than $320 \mathrm{mOsm} / \mathrm{kg} \mathrm{H}_{2} \mathrm{O}[1,2,7]$. The choice 
of agents depends on clinical experience and local protocol, however HTS is frequently used to reduce $\mathrm{ICH}$ as well as tissue edema, whereas mannitol is used only to reduce $\mathrm{ICH}[8,9]$.

\section{The Most Popular Hyperosmotic Agents}

The main problem for choosing hyperosmotic agents is their different osmotic activity. The reflection coefficient (a number which reflects the difficulty for the molecule to pass through the endothelium: $0=$ fully permeable and $1.0=$ completely impermeable) is 0.9 in the normal brain and a little less in the injured brain [10]. It means that mannitol practically did not pass through the BBB, but it penetrates the injured BBB and the intact BBB. Mannitol at a daily dose of $0.5-1.5 \mathrm{~g} / \mathrm{kg}$ body weight is commonly used as an osmotically active medication in patients with TBI. Chemically, it is a metabolically inert sugar alcohol $\left(\mathrm{C}_{6} \mathrm{H}_{14} \mathrm{O}_{6}\right)$, which is similar to xylitol or sorbitol. It elevates plasma osmolality, which enhances flow from the extravascular to the intravascular space. Interestingly, inhaled mannitol was also indicated by the Food and Drug Administration (FDA) in the treatment of cystic fibrosis in the lung [11,12].

HTS elevates plasma osmolality via plasma increase in osmotically active ions, such as sodium. Additionally, HTS also reduces single erythrocyte volume, improving their passage through the capillaries. Its reflection coefficient is $1[13,14]$. It seems to reduce ICH and improve cerebral perfusion pressure more effectively than mannitol [15-17]. Some studies also documented better outcomes in patients treated with HTS compared to mannitol, however the osmotherapy-related electrolyte disequilibrium appears to be an independent predictor of poor outcome, regardless of the type of osmotically active medication [18-20]. This improves the rheological properties of the blood and the osmotic activity of aquaporin receptors in the BBB [21,22]. Clinicians commonly use HTS with different $3 \%, 7.5 \%$, or $23.4 \%$ solutions, and each of those presents a different osmotic activity (Table 1) [21,22]. Regardless of the type of the osmotically active agents, the main target of osmotherapy is to maintain plasma osmolality around $300-320 \mathrm{mOsm} / \mathrm{kg} \mathrm{H}_{2} \mathrm{O}[1,2]$.

Table 1. Theoretical osmolality of the most popular osmotically active agents [17-25].

\begin{tabular}{|c|c|c|c|c|c|c|c|c|}
\hline Solution & $\begin{array}{c}0.9 \% \\
\mathrm{NaCl}\end{array}$ & $\begin{array}{c}3 \% \\
\mathrm{NaCl}\end{array}$ & $\begin{array}{l}7.5 \% \\
\mathrm{NaCl}\end{array}$ & $\begin{array}{l}23.4 \% \\
\mathrm{NaCl}\end{array}$ & $\begin{array}{c}10 \% \\
\text { Mannitol }\end{array}$ & $\begin{array}{c}15 \% \\
\text { Mannitol }\end{array}$ & $\begin{array}{c}20 \% \\
\text { Mannitol }\end{array}$ & $\begin{array}{c}1 \% \text { o } \\
\text { Ethanol }\end{array}$ \\
\hline $\begin{array}{c}\text { Osmolality } \\
\left(\mathrm{mOsm} / \mathrm{kg} \mathrm{H}_{2} \mathrm{O}\right)\end{array}$ & 308 & 1026 & 2567 & 8008 & 550 & 825 & 1100 & 22 \\
\hline
\end{tabular}

\section{Basic Knowledge}

Hyperosmotic therapy is based on osmosis-a phenomenon in which the water molecules migrate through a semi-permeable barrier from a solution rich in osmotically active molecules to a solution poor in the concentration of these agents. The difference in solutes, which cannot pass across the semi-permeable membrane, causes a chemical potential. According to the Gibbs-Duhen equation, the chemical potential and activity of water molecules is higher in a solvent in which the activity of saluted agents is lower, and the movement of water is forced from the solvent to the solution [26]. Osmolarity is defined as the number of solutes per liter of solution, however the concentration of solutes is very low in human body fluids. Therefore, the plasma osmolarity is calculated in milliosmoles (mOsm/L). Osmolality is defined as the number of milliosmoles of solutes per one kilogram of water (mOsm $/ \mathrm{kg} \mathrm{H}_{2} \mathrm{O}$ ). Physiologically, $\mathrm{Na}^{+}, \mathrm{K}^{+}, \mathrm{Cl}^{-}, \mathrm{HCO}_{3}{ }^{-}$, glucose, and urea are the main osmotically active substances in the human body, however a lot of medicaments exhibit osmotic properties. Some of them, such as urea and ethanol, freely cross the cell membranes and are called "ineffective osmoles", whereas others such as $\mathrm{Na}^{+}$, $\mathrm{K}^{+}, \mathrm{Cl}^{-}, \mathrm{HCO}_{3}{ }^{-}$, and glucose are called effective osmoles because they do not cross the cell membranes, forcing water shifts through the cellular membranes (tonicity). Chemically, osmolarity is strongly related to osmolality in solutions with the same composition but 
different concentrations of osmotically active agents. These relationship changes occur in the blood because the blood contains lipids, proteins, and others small solutes contributing to plasma osmolality, thus sodium solutions are not completely dissociated in the aqueous medium. Additionally, the plasma contains only $93 \%$ of water [27]. Therefore, plasma osmolality can be calculated by multiplying the plasma osmolarity by 0.93 . Hence, osmotic pressure is more closely related to plasma osmolality than osmolarity. Plasma osmolality should be measured by a cryoscopy technique, which is considered as the reference method for osmolality measurement [28]. However, several clinicians have calculated plasma osmolality using a different equation. The most popular, the simplest, and the best is known as the Worthley equation $[25,27]$ :

Plasma osmolality $=2 x \mathrm{Na}^{+}+\frac{\text { Glucose }(\mathrm{mg} / \mathrm{dL})}{18}+\frac{B U N(\mathrm{mg} / \mathrm{dL})}{2.8}=275-295 \mathrm{mOsm} / \mathrm{kg} \mathrm{H} \mathrm{H}_{2} \mathrm{O}$

The difference between the measured and the calculated plasma osmolality is called the osmolal gap. Physiologically, its value ranges between -10 and $+10 \mathrm{mOsm} / \mathrm{L}$. An osmolal gap higher than $10 \mathrm{mOsm} / \mathrm{L}$ documents the presence of osmotically active agents in the blood, while its values above $20 \mathrm{mOsm} / \mathrm{L}$ suggest blood intoxication with strong osmotic substances [29-31]. Despite the beneficial effect of elevated plasma osmolality on cerebral water content in TBI patients with cerebral edema, hyperosmolality per se or associated with high osmolal gap may affect organ function, increase the risk of multiorgan dysfunction, and worsen the outcome in critically ill patients (Figure 1) [30-34]. The aim of this article was to provide a narrative review regarding the effect of recommended plasma hyperosmolality on organ function in patients treated for TBI.

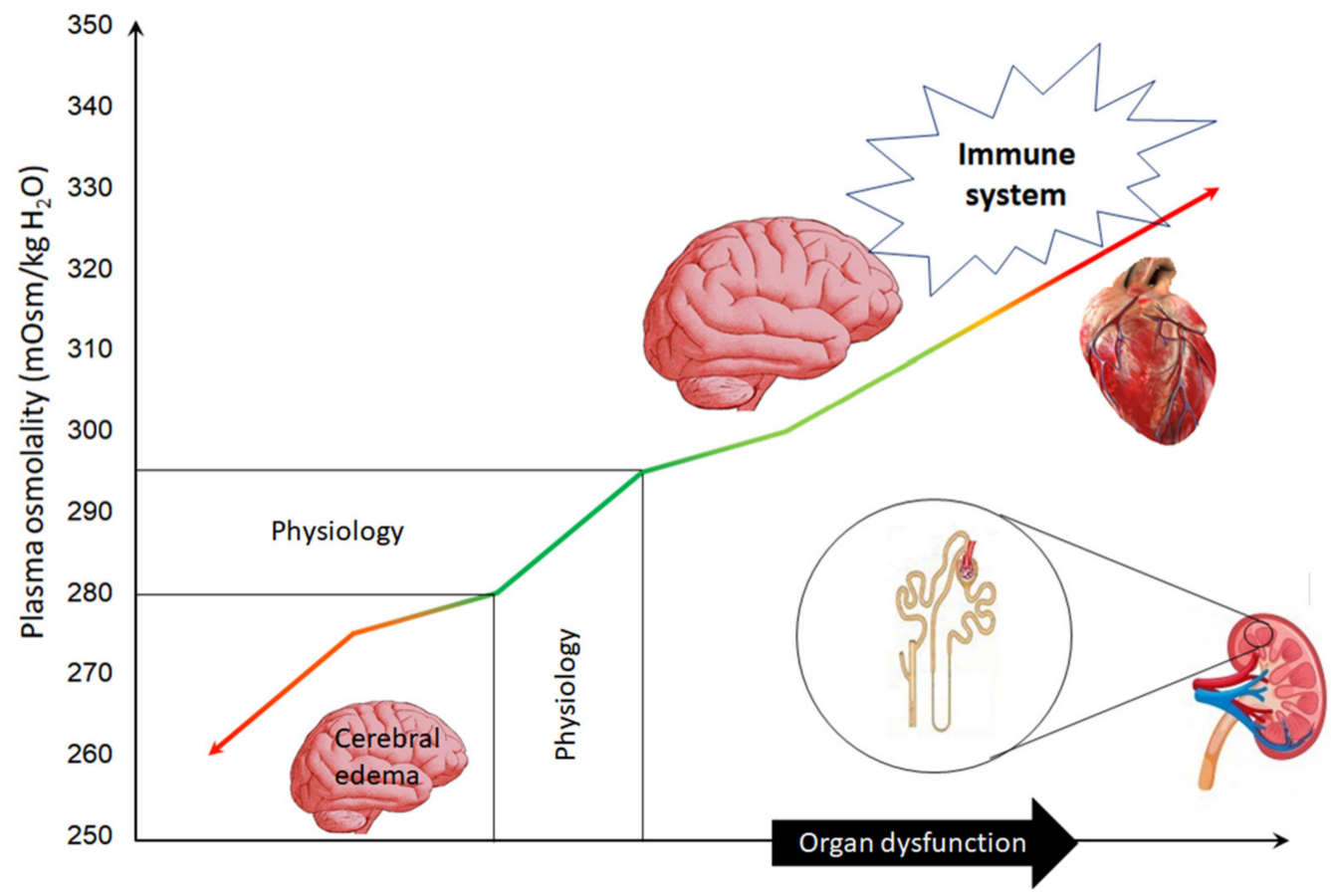

Figure 1. General scheme showing the organs that can be damaged as a result of increased plasma osmolality.

\section{Plasma Hyperosmolality and the Heart}

The disorders of plasma osmolality can impair cardiac function and increase the risk of life-threatening cardiac arrhythmias and sudden cardiac death [32,35-38]. An analysis of relationships between plasma osmolality, and the 30-day and 1-year outcomes in 985 patients diagnosed with acute coronary syndrome, showed a significantly higher mortality rate in patients with hyperosmolal plasma [38]. Another clinical analysis of 3748 patients treated for acute coronary diseases also documented an increase in short and 
long mortality in patients with hyperosmolality [36]. Interestingly, the rate of ventricular arrhythmias, cardiogenic shock, and major adverse cardiac events was two-fold higher in those patients. Indeed, an increase in plasma osmolality following mannitol administration above $313 \mathrm{mOsm} / \mathrm{kg} \mathrm{H}_{2} \mathrm{O}$ significantly increased the risk for prolongation of corrected QT interval above $500 \mathrm{~ms}$, which is associated with the incidence of atrial fibrillation in patients without any cardiac history treated for TBI [32]. An experimental study has shown that HTS-induced hyperosmolality per se may exert potentially deleterious effects on myocardial contractility, leading to systolic and diastolic dysfunction, cytosolic $\mathrm{Ca}^{2+}$ accumulation with diastolic contracture, and increased susceptibility to life-threatening arrhythmias [27]. Additionally, HTS-related hyperosmotic stress is associated with an increase in the intracellular $\mathrm{Ca}^{2+}$ concentration and generation of reactive oxygen species, which promotes stress in the endoplasmic reticulum, leading to apoptosis and death of adult and neonatal cardiomyocytes [39,40]. Plasma osmolality plays a crucial role in the function of cardiac aquaporins. Hyperosmolality increases the mRNA of aquaporin-1, mRNA of upregulated aquaporin-7, protein glycosylation, and intracellular translocation, which may modulate water transport in cardiac myocytes [41-43]. A rapid increase in plasma osmolality following hypertonic saline administration depresses the sensitivity of the cardiac baroreflex independently of changes in blood pressure, causing an increase in heart rate [44]. Accumulating data have shown that a rapid increase in plasma osmolality activates sympathetic nerve activity, both in humans and animals [45-47]. Moreover, prolonged hyperosmolality also increases sympathetic nerve activity through activation of osmoreceptors and raised excitatory amino acid release in the forebrain $[47,48]$. A dysregulation of sympathetic/parasympathetic activity as well as dysfunction of cardiac myocytes following an increase in plasma osmolality may depress cardiac function, leading to acute cardiac failure. Thus, it can be speculated that hyperosmolality may play an important role in cardiac dysfunction that develops in patients treated for TBI, which is commonly known as the brain-heart interaction.

In some clinical situations, hyperosmolality may also have a beneficial effect on cardiac function. Experimental studies documented that hyperosmotic perfusion significantly reduced total and intracellular myocardial water content, reduced sarcolemmal rupture, and increased coronary flow in ischemia/reperfusion-induced cellular edema $[49,50]$. Another study documented that hyperosmotic pretreatment also reduced the infarct size following regional-induced ischemia in a rat heart model [51]. The beneficial effect of hyperosmotic perfusion after cardiac ischemia may be explained by the relatively small osmotic gradient between the intra- and extra-cellular spaces during reperfusion. An increase of the level of intracellular lactate following ischemia-induced anaerobic glycolysis results in a relative hyperosmotic condition within the ischemic area. Hence, the normo- or hypo-osmotic reperfusion increases the water shift from the vascular into the intracellular space, leading to cellular edema, whereas hyperosmotic reperfusion does not induce water extravasation (Figure 2). It is also worth stressing that a lot of research analyzing the beneficial effect of hyperosmolal reperfusion in ischemic heart with swollen cardiomyocytes showed that the increased osmolality of the perfusate (with mannitol) had cardioprotective properties [52]. Taken together, we can suggest that hyperosmolality may impair cardiac function in TBI patients without any previous history of cardiac diseases. Hence, osmotherapy requires strict control of plasma osmolality (not osmolarity). 


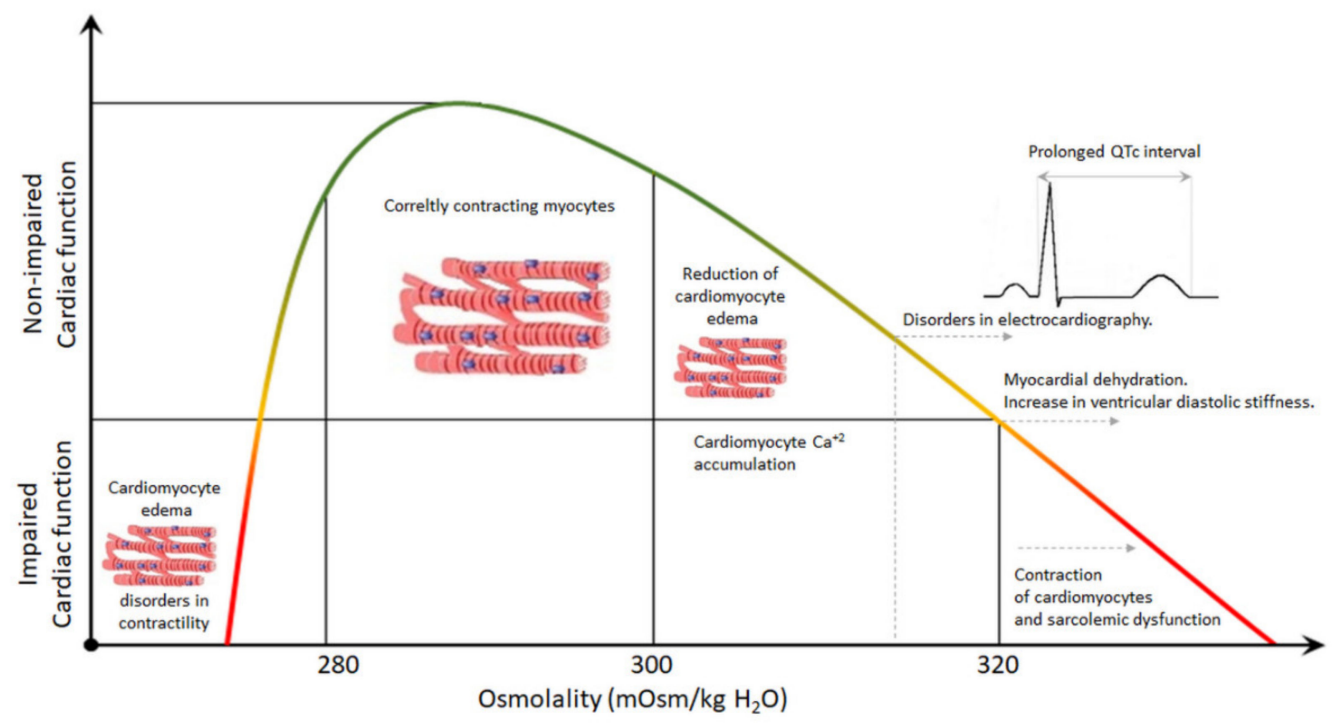

Figure 2. General scheme showing the effect of hyperosmolality on the heart.

\section{Plasma Hyperosmolality and the Kidney}

Kidneys are especially vulnerable to disorders in plasma osmolality because they play a crucial role in plasma osmolality regulation. The kidney is responsible for regulation of salt and water excretion. Under physiological conditions, sodium is the predominant cation affecting fluid osmolality in mammals, and the osmoregulation and the control of total body sodium operate independently to its plasma concentration, at least to some extent [53]. Several factors play a role in the regulation of kidney excretory function, and inner medullary cells are especially vulnerable to elevation of plasma osmolality. Hyperosmolality induces salt excretion, increasing its concentration in urea and inner medullary cells. This process forces increased urea removal. It is noteworthy that $\mathrm{Na}^{+}$and $\mathrm{Cl}^{-}$exert different effects on cells due to their different permeability of the cell membranes, whereas urea penetrates the cell membrane similarly to water. Extracellular hypertonicity following elevated extracellular salt content increases passive water shift from the intracellular into the extracellular space, leading to cellular shrinkage. On the other hand, elevated urea concentration in the extracellular space forces its shift to the inner medullary cells due to osmosis. Accumulated intracellular urea is a trigger for uncontrolled protein denaturation. Additionally, the nonspecific effect of hyperosmolality may result from osmolar-forced diuresis with activation of tubulo-glomerular feedback associated with an increase in hydrostatic pressure in the tubules and a decrease in intrarenal microcirculation flow, which ultimately reduces the glomerular filtration rate. An impairment of renal blood flow disturbs oxygen delivery to the renal cells, inducing hypoxia-related cell damage [54]. Hence, hyperosmolality itself affects cell volume, cell metabolism, intracellular ion homeostasis, and stability of nucleic acids, which can induce an apoptotic process and upregulate several genes in the renal inner medullary cells [55-58]. A lot of osmotically active agents may also induce or intensify hyperosmosis-related acute kidney injury (AKI). This pathology is commonly known as "osmotic nephrosis" or "sucrose nephrosis" (Figure 3). Several studies showed that intravenous administration of immune globulin, mannitol, contrast media, hydroxyethyl starch solutions, or glucose can induce AKI injury via osmotic cell destruction [59-65]. It was well-documented that osmotically active agents entered the tubular cells by means of pinocytosis, leading to cellular edema with increased lysosomes and endocytotic vacuoles. Interestingly, the use of iso-osmolar contrast media also results in nephrotoxicity, similar to the effect of the hyperosmolar media, which cannot be explained by hyperosmolality itself, but rather the increased viscosity of the iso-osmolar agents [65,66]. However, plasma osmolality plays an important role for renal function. Clinical observations documented a significant relationship between plasma osmolality and a higher incidence of AKI noted in 
patients with diabetic ketoacidosis when osmolality exceeded $320 \mathrm{mOsm} / \mathrm{kg}[67,68]$. The osmotic nephrosis is usually reversible after discontinuation of osmotically active agents; however, some patients require temporary renal replacement therapy [63,68-71].

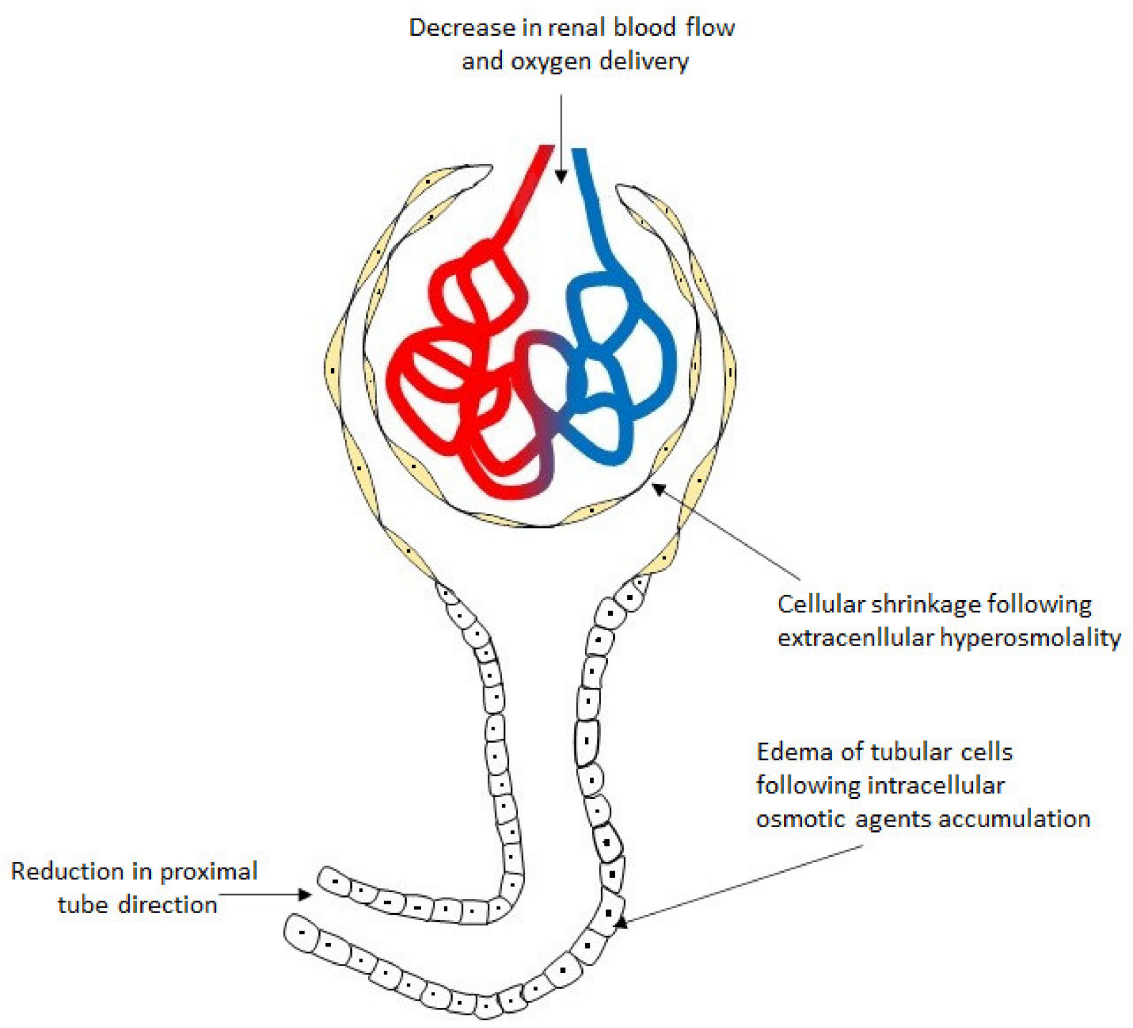

Figure 3. General scheme presenting an effect of hyperosmosis on glomerulus and tubular cells $[54-57,66]$.

Mannitol is not recommended for use in the management of severe TBI when ICP and brain tissue oxygen are monitored [2]. Several studies documented AKI following mannitol administration [62,69-71]. Mannitol-induced osmotic nephrosis has been well-documented, as it exerts nephrotoxic activity [61-63,65,72]. There is a dose-response relationship between the use of mannitol and the incidence and severity of AKI, with a cut-off of the daily dose at $1.34 \mathrm{~g} / \mathrm{kg}$ body weight [73]. Interestingly, the combined therapy of ICH with mannitol and HTS did not increase the risk of AKI more than HTS alone, however several authors suggested to use HTS, demonstrating its superiority over mannitol [13,14,16,18,74]. In conclusion, it can be postulated that an increase in plasma hyperosmolality per se, as well as the use of osmotically active medications, may impair renal function, and that maintaining adequate renal perfusion may reduce the risk of AKI.

\section{Plasma Hyperosmolality and Immune System}

The effects of hyperosmolality on the immune system are still controversial and not very well-recognized, however several in vitro studies have attributed an important role to hypertonicity in the inflammatory response [75-80]. Elevated plasma osmolality is especially associated with stimulation of macrophages and dendric cells $[5,75]$. An increase in plasma osmolality by 10 to $20 \mathrm{mOsm} / \mathrm{kg}$ suppresses neutrophil function by modulating cellular signaling, fosters B cell activation and differentiation, and reduces macrophage activation [5,76-78]. Several experimental studies have documented that increasing tonicity inhibits the production of proinflammatory cytokines in pulmonary epithelial cells $[78,79]$. The inhibitory effect of hypertonicity on inflammatory responses is especially important after brain injury. An increase in plasma osmolality following mannitol or HTS admin- 
istration reduces microglial activation and promotes the anti-inflammatory phagocytic M2-like microglial phenotype in an experimental model of intracerebral hemorrhage [5]. Such relationships between hyperosmolality and the inflammatory response may result from direct regulation of nuclear factor in the T cells, which affect TNF- $\alpha$ and lymphotoxin$\beta$ [80]. Additionally, hyperosmotic stress leads to cell apoptosis that involves changes in the apoptotic signaling molecules such as mitogen-activated protein kinase, c-Jun amino terminal kinase, mitogen-activated kinase, and p38 mitogen-activated kinase in a primary cultured nucleus pulpous cells [81]. Hyperosmolarity following mannitol administration at the dose of $1.0-1.5 \mathrm{~g} / \mathrm{kg}$ body weight induces programmed cell death in a dose-dependent manner in both endothelial and smooth muscle cells [82]. The cell loss within the endothelial monolayers was the most pronounced, with serum osmolarity above $320 \mathrm{mOsm} / \mathrm{L}$. Quite the opposite, it has been documented that hyperosmotic stress is associated with pro-inflammatory cytokine secretion, such as: TNF, IL1- $\beta$, IL-6, and IL-8, and that hyperosmolality may be an important factor for survival of macrophages at the inflammatory site after injection of the Bacille Calmette-Guerin (BCG) vaccine [83]. Additionally, prolonged dietary sodium administration increases activation of stress-sensitive neurons of the hypothalamic paraventricular nucleus and basolateral amygdala, leading to stress coping behaviors in mice [84]. In a clinical study including 44 healthy volunteers who received a $250 \mathrm{~mL}$ intravenous bolus of $3 \%$ saline solution to increase plasma osmolality to $315 \mathrm{mOsm} / \mathrm{L}$, the authors showed that both hyponatremia and plasma hyperosmolality did not induce an increase in circulating markers of inflammation and led to a decrease in the level of TNF $\alpha$ and IL-8 at an unchanged level of IL-6 plasma concentration [85]. Another study documented that the increase in plasma osmolality following mannitol at a dose of $0.5 \mathrm{~g} / \mathrm{kg}$ body weight significantly limited cardiopulmonary bypass-related inflammatory response, with a reduction of pro-inflammatory and an increase of antiinflammatory cytokines [86]. It is noteworthy that the majority of studies analyzing the effects of hyperosmolality on the immune system are based on experimental observations. Therefore, one can only speculate that hyperosmolality seems to have a beneficial effect on the immune system, and this hypothesis should be confirmed in further studies.

\section{Plasma Hyperosmolality and the Blood-Brain Barrier}

Hyperosmolar therapy is the cornerstone treatment of ICH. Administration of hyperosmolar agents increases the osmotic gradient between blood and brain, forcing the water flux from the brain to blood through the BBB. In the central nervous system of mammals, the BBB is created at the level of the endothelial brain cells, where multiple protein complexes accumulate at the cell-junctions, restricting the paracellular diffusion of ions and other polar solutes, hence effectively blocking the penetration of macromolecules. Unfortunately, therapeutic hyperosmolar agents can reversibly open thigh junctions in the cerebrovascular endothelium, and their conductivity depends on the degree of plasma hyperosmolality [87-90]. An experimental study has shown a temporal induction of neuroinflammatory response following intracarotid infusion of mannitol [89]. Elevation of cytokines, chemokines, trophic factors, and cell adhesion molecules was noted within 5 min after mannitol administration that persisted for 4 days. It is noteworthy that the BBB's susceptibility to increase plasma osmolality decreases with age and is the greatest in fetuses and premature infants [90].

Currently, the effect of a rapid increase of plasma osmolality on the function of the BBB is used to increase delivery of poorly penetrating medications to the brain (Figure 4). This type of treatment may be especially attractive for treating malignant brain tumors [91,92]. Administration of a small volume of chemotherapeutics after mannitol into the tumor circulation increases their therapeutic properties without the need for increased systemic doses and without adverse effects [91]. A lot of preclinical and clinical studies have convincingly documented the high potency of this approach to elevate the delivery of chemotherapy and other medications to the brain. Experimental studies have also presented a better brain delivery of other drugs, such as antiepileptic drugs or docosahexaenoic acid (DHA), in 
hypertonicity-related hyperpermeability of the BBB [93,94]. Interestingly, an increase of DHA attenuates BBB disruption, and reduces cerebral edema and TBI-induced neuroinflammation [94,95].

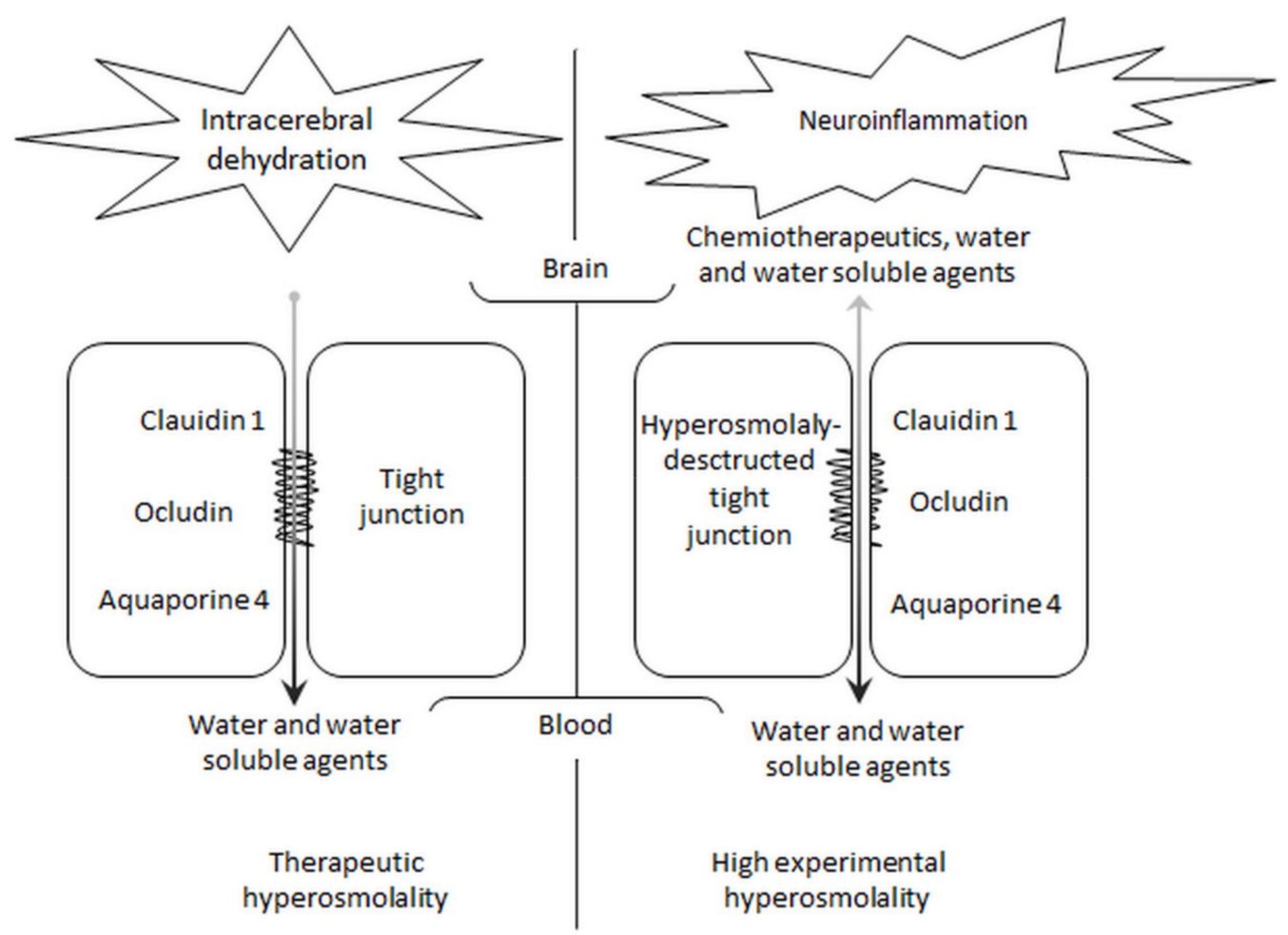

Figure 4. General scheme showing the effect of hyperosmolality on the blood-brain barrier. Therapeutic increase in plasma osmolality intense water removal from the brain. Experimentally raised osmolality to the high value disrupts the blood-brain barrier from opening the tight junction for intracerebral shifts of chemotherapeutics, water, and other water-soluble and insoluble agents.

It is difficult to show a destructive effect of plasma hyperosmolality on the BBB in patients treated for TBI. An experimental and therapeutic decrease in BBB permeability is induced by intra-arterial administration of mannitol. Hence, many clinicians prefer HTS over mannitol to increase plasma osmolality, because HTS does not affect the BBB permeability. However, a decrease in BBB permeability following hypertonicity seems to be useful in treating secondary brain damage from different antioxidants and antiinflammatory agents. This hypothesis needs confirmation in future studies.

\section{Conclusions}

Osmotherapy is the cornerstone treatment of ICH. An increase in plasma osmolality to the recommended $320 \mathrm{mOsm} / \mathrm{kg} \mathrm{H}_{2} \mathrm{O}$ is commonly achieved by mannitol or HTS. The choice of osmotic agents is still the subject of debate, and HTS seems to be preferred over mannitol. An increase in plasma osmolality may impair cardiac, kidney, immune, and BBB function, however a deleterious effect of mannitol-induced hyperosmolality has only been clinically documented with respect to kidney and cardiac function. An increase in plasma osmolality per se above $313 \mathrm{mOsm} / \mathrm{kg} \mathrm{H}_{2} \mathrm{O}$ may by itself impair cardiac function. Future trials are awaited to bring more answers and solutions.

Author Contributions: W.D., A.J., C.R. and R.B. (Romuald Bohatyrewicz) reviewed the concept; D.S.-G., W.D., K.K., M.B., J.S.-P., C.R. and R.B. (Rafael Badenes) performed literature collection and analysis; W.D., M.L.N.G.M. and A.J. drafted the first version; K.K. reviewed the initial draft. All authors have read and agreed to the published version of the manuscript.

Funding: This research received no external funding. 


\section{Data Availability Statement: Not applicable—not original data.}

Conflicts of Interest: The authors declare no conflict of interest.

\section{References}

1. Raslan, A.; Bhardwaj, A. Medical management of cerebral edema. Neurosurg. Focus 2007, 22, E12. [CrossRef]

2. Chesnut, R.; Aguilera, S.; Buki, A.; Bulger, E.; Citerio, G.; Cooper, D.J.; Arradtia, R.D.; Diringer, M.; Figaji, A.; Gao, G.; et al. A management algorithm for patients with intracranial pressure monitoring: The Seattle International Severe Traumatic Brain Injury Consensus Conference (SIBICC). Intensive Care Med. 2020, 46, 1783-1794. [CrossRef]

3. Macintyre, I. A hotbed of medical innovation: George Kellie (1770-1829), his colleagues at Leith and the Monro-Kellie doctrine. J. Med. Biogr. 2014, 22, 93-100. [CrossRef] [PubMed]

4. Mokri, B. The Monro-Kellie hypothesis: Applications in CSF volume depletion. Neurology 2001, 56, 1746-1748. [CrossRef] [PubMed]

5. Schreibman, D.L.; Hong, C.M.; Keledjian, K.; Ivanowa, S.; Tsymbalyuk, S.; Gerzanich, V.; Simard, J.M. Mannitol and hypertonic saline reduce swelling and modulate inflammatory markers in a rat model of intracerebral haemorrhage. Neurocrit. Care 2018, 29, 253-263. [CrossRef] [PubMed]

6. Pascual, J.L.; Ferri, L.E.; Seely, A.J.E.; Campisi, G.; Chaudhury, P.; Giannias, B.; Evans, D.C.; Razek, T.; Michel, R.P.; Cgristou, N.V. Hypertonic saline resuscitation of hemorrhagic shock diminishes neutrophil rolling and adherence to endothelium and reduces in vivo vascular leakage. Ann. Surg. 2002, 236, 634-642. [CrossRef] [PubMed]

7. Oddo, M.; Poole, D.; Helbok, R.; Meyfroidt, G.; Stocchetti, N.; Bouzat, P.; Cecconi, M.; Geeraets, T.; Martin-Loeches, I.; Quintard, H.; et al. Fluid therapy in neurointensive care patients: ESCIM consensus and clinical practice recommendations. Intenvive Care Med. 2018, 44, 449-463. [CrossRef] [PubMed]

8. Toung, T.J.; Chen, C.H.; Lin, C.; Bhardwaj, A. Osmotherapy with hypertonic saline attenuates water content in brain and extracerebral organs. Crit. Care Med. 2007, 35, 526-531. [CrossRef]

9. Hays, A.N.; Lazaridis, C.; Neyens, R.; Nicholas, J.; Gay, S.; Chalela, J.A. Osmotherapy: Use among neurointensivists. Neurocrit Care 2011, 14, 222-228. [CrossRef]

10. Bhardwaj, A. Osmotherapy in neurocritical care. Curr. Neurol. Neurosci. Rep. 2007, 7, 513-521. [CrossRef]

11. FDA Approved Drug Products: BRONCHITOL (mannitol) Oral Inhalation Power. Available online: https://www.accessdata.fda. gov/drugsatfda_docs/label/2020/202049s000lbl.pdf (accessed on 30 October 2020).

12. Southern, K.W.; Clancy, J.P.; Ranganathan, S. Aerosolized agents for airway clearance in cystic fibrosis. Pediatr. Pulmonol. 2019, 54, 858-864. [CrossRef]

13. Georgidis, A.L.; Suarez, J.I. Hypertonic saline for cerebral edema. Curr. Neurol. Neurosci. Rep. 2003, 6, 524-530. [CrossRef]

14. Kheirbek, T.; Pascual, J.L. Hypertonic saline for the treatment of intracranial hypertension. Curr. Neurol. Neurosci. Rep. 2014, 14, 482. [CrossRef] [PubMed]

15. Badaut, J.; Ashwal, S.; Obenaus, A. Aquaporins in cerebrovascular disease: A target for treatment of brain edema? Cerebrovasc Dis. 2011, 31, 521-531. [CrossRef] [PubMed]

16. Badenes, R.; Hutton, B.; Citerio, G.; Robba, C.; Aguilar, G.; Alonso-Arroyo, A.; Taccone, F.S.; Tornero, C.; Catala-Lopez, F. Hyperosmolar therapy for acute brain injury: Study protocol for an umbrella rewie of meta-analyses and evidence mapping. BMJ Open 2020, 10, e033913. [CrossRef] [PubMed]

17. Himmelsehr, S. Hypertonic saline solutions for treatment of intracranial hypertension. Curr. Opin. Anaesthesiol. 2007, 20, 414-426. [CrossRef] [PubMed]

18. Garrard, A.; Sollee, D.R.; Butterfiels, R.C.; Johannsen, L.; Wood, A.; Bertholf, R.L. Validation of pre-existing formula to calculate the contribution of ethanol to the osmolar gap. Clin. Toxicol. 2012, 50,562-566. [CrossRef]

19. Cochrane, T.T. Improvements in the equation for calculating the contribution to osmotic potential of the separate solutes of water solutions. Med. Phys. 1984, 11, 338-340. [CrossRef] [PubMed]

20. Moucka, F.; Nezbeda, I.; Smith, W.R. Molecular simulation of aqueous electrocytes: Water chemical potential results and Gibbs-Duhem equation consistency tests. J. Chem. Phys. 2013, 139, 124505. [CrossRef]

21. Rasouli, M.; Kalantari, K.R. Comparison of methods for calculating serum osmolality: Multivariate linear regression analysis. Clin. Chem. Lab. Med. 2005, 43, 635-640. [CrossRef]

22. Sweeney, T.E.; Beuchat, C.A. Limitation of methods of osmometry: Measuring the osmolality of biological FLUIDS. Am. J. Physiol. 1993, 264, R469-R480. [CrossRef] [PubMed]

23. Kruse, J.A.; Cadnapaphornachai, P. The serum osmole gap. J. Crit. Care 1994, 9, 185-197. [CrossRef]

24. Skaaland, H.; Larstorp, A.C.K.; Lindberg, M.; Jacobsen, D. Reference values for osmolal gap in healthy subject and in medical inpatients. Scand. J. Clin. Lab. Investig. 2020, 80, 1-5. [CrossRef] [PubMed]

25. Liams, G.; Fillppatos, T.D.; Liontos, A.; Elisaf, M.S. Serum osmolal gap in clinical practice: Usefulness and limitations. Postgrad. Med. 2017, 129, 456-459. [CrossRef]

26. Dabrowski, W.; Siwicka-Gieroba, D.; Robba, C.; Badenes, R.; Bialy, M.; Iwaniuk, P.; Schlegel, T.T.; Jaroszynski, A. Plasma hyperosmolality prolongs QTc interval and increases rosk for atrial fibrillation in traumatic brain injury patients. J. Clin. Med. 2020, 9, 1293. [CrossRef]

27. Bealer, S.L. Peripheral hyperosmolality reduces cardiac baroreflex sensitivity. Auton. Neurosci. 2003, 104, 24-31. [CrossRef] 
28. Kultz, D. Hyperosmolality triggers oxidative damage in kidney cells. Proc. Nat. Acad. Sci. USA 2004, 101, 9177-9178. [CrossRef]

29. Steinberg, C. Diagnosis and clinical management of long-QT syndrome. Curr. Opin. Cardiol. 2018, 33, 31-41. [CrossRef]

30. Tatlisu, M.A.; Kaya, A.; Keskin, M.; Uzman, O.; Borklu, E.B.; Cinier, G.; Hayiroglu, M.I.; Tatlisu, K.; Eren, M. Can we use plasma hyperosmolality as a predictor of mortality for ST-segment elevation myocardial infarction? Coron. Artery Dis. 2017, $28,70-76$. [CrossRef]

31. Kaya, H.; Yücel, O.; Ege, M.R.; Zorlu, A.; Yücel, H.; Günes, H.; Ekmekci, A.; Yilmaz, M.B. Plasma osmolality predicts mortality in patients with heart failure with reduced ejection fraction. Kardiol. Pol. 2017, 75, 316-322. [CrossRef]

32. Rohla, M.; Freynhofer, M.K.; Tentzeris, I.; Farhan, S.; Wojte, J.; Huber, K.; Weiss, T.W. Plasma osmolality predicts clinical outcome in patients with acute coronary syndrome undergoing percutaneous coronary intervention. Eur. Heart J. Acuta Cardiovasc. Care 2014, 3, 84-92. [CrossRef] [PubMed]

33. Ricardo, R.A.; Bassani, R.A.; Bassani, J.W.M. Osmolality- and Na+-dependent effect of hyperosmotic NaCl solution on contractile activity and Ca2+ cycling in rat ventricular myocytes. Pflugers Arch. 2008, 455, 617-626. [CrossRef] [PubMed]

34. Burgos, J.I.; Morell, M.; Mariangelo, J.I.E.; Petroff, M.V. Hyperosmotic stress promotes endoplasmic reticulum stress-dependent apoptosis in adult rat cardiac myocytes. Apoptosis 2019, 24, 785-797. [CrossRef]

35. Galvez, A.; Morales, M.P.; Eltit, J.M.; Ocaranza, P.; Carrasco, L.; Campos, X.; Sapag-Hagar, M.; Díaz-Araya, G.; Lavandero, S. A rapid and strong apoptotic process is triggering by hyperosmotic stress in cultured rat cardiac myocytes. Cell Tissue Res. 2001, 304, 279-285. [CrossRef]

36. Page, E.; Winterfield, J.; Goings, G.; Bastawrous, A.; Upshaw-Early, J. Water channel proteins in rat cardiac myocyte caveolae: Osmolarity-dependent reversible internalization. Am. J. Physiol. 1998, 274, H1988-H2000. [CrossRef]

37. Rutkovskiy, A.; Mariero, L.H.; Nygard, S.; Stenslokken, K.O.; Valen, G.; Vaage, J. Transient hyperosmolality modulates expression of cardiac aquaporins. Biochem. Biophys. Res. Commun. 2012, 425, 70-75. [CrossRef]

38. Aggeli, I.K.; Kapogiannatou, A.; Paraskevopoulou, F.; Gaitanaki, C. Differential response of cardiac aquaporins of hyperosmotic stress; salutary role of AQ1 against the induced apoptosis. Eur. Rev. Med. Pharmacol. Sci. 2021, 25, 313-325.

39. Farquhar, W.B.; Wenner, M.M.; Delaney, E.P.; Prettyman, A.V.; Stillabower, M.E. Sympathetic neural response to increased osmolality in humans. Am. J. Physiol. Heart Circ. Physiol. 2006, 291, H2181-H2186. [CrossRef] [PubMed]

40. Kinsman, B.J.; Browning, K.N.; Stocker, S.D. $\mathrm{NaCl}$ and osmolarity produce different responses in organum vasculosum if the lamina terminalis neurons, sympathetic nerve activity and blood pressure. J. Physiol. 2017, 595, 6187-6201. [CrossRef]

41. Brooks, V.L.; Freeman, K.L.; O'Donaughy, T.L. Acute and chronic increase in osmolality increase excitatory amino acid drive of the rostral ventrolateral medulla in rats. Am. J. Physiol. Regul. Integr. Comp. Physiol. 2004, 287, R1359-R1368. [CrossRef] [PubMed]

42. Kamijo, Y.I.; Okazaki, K.; Ikegawa, S.; Okada, Y.; Nose, H. Rapid saline infusion and/or drinking enhance skin sympathetic nerve activity components reduced by hypovolaemia and hyperosmolality in hyperthermia. J. Physiol. 2018, 596, 544-5459. [CrossRef]

43. Andreas-Villarreal, M.; Barba, I.; Poncelas, M.; Inserte, J.; Rodriguea-Palomares, J.; Pineda, V.; Gracia-Dorado, D. Measuring water distribution in the heart: Preventing edema reducas ischemia-reperfusion injury. J. Am. Hert. Assoc. 2016, 5, e003843. [CrossRef]

44. Cao, Y.; Wang, L.; Chen, H.; Lv, Z. Beneficial effect of hyperosmotic perfusion in the myocardium after ischemia/reperfusion injury in isolated rat hearts. Rev. Bras. Cir. Cardiovasc. 2013, 28, 545-560. [CrossRef]

45. Falck, G.; Schjott, J.; Jynge, P. Hyperosmotic pretreatment reduces infarct size in the rat heart. Physiol. Rev. 1999, 48, 331-340.

46. Feige, K.; Rubbert, J.; Raupach, A.; Stroethoff, M.; Heinen, A.; Hollmann, M.W.; Huhn, R.; Torregroza, C. Cardioprotective properties of mannitol-involvement of mitochondrial potassium channels. Int. J. Mol. Sci. 2021, 22, 2395. [CrossRef]

47. Bie, P.; Damkjaer, M. Renin secretion and total body sodium: Pathways of integrative control. Clin. Exp. Pharmacol. Physiol. 2010, 37, e34-e42. [CrossRef] [PubMed]

48. Bansal, S.; Patel, R.N. Pathophysiology of contrast-induced acute kidney injury. Interv. Cardiol. Clin. 2020, 9, 293-298. [CrossRef] [PubMed]

49. Berl, T. How do kidney cells adopt to survive in hypertonic inner medulla? Trans. Am. Clin. Climatol. Assoc. 2009, $120,389-401$.

50. Blasum, B.S.; Schröter, R.; Neugebauer, U.; Hofchsröer, V.; Pavenstädt, H.; Ciarimboli, G.; Schlatter, E.; Edemir, B. The kidneysepcific expression of genes can be modulated by the extracellular osmolality. FASEB J. 2016, 30, 3588-3597. [CrossRef]

51. Orbach, H.; Tishler, M.; Shoenfeld, Y. Intravenous immunoglobulin and the kidney-A two-edged sword. Semin. Arthritis Rheum. 2004, 34, 593-601. [CrossRef]

52. Kwan, T.H.; Tong, M.K.; Siu, Y.P.; Leung, K.T.; Lee, H.K.; Young, C.Y.; Au, T.C. Acute renal failure related to intravenous immunoglobulin infusion in an elderly woman. Hong Kong Med. J. 2005, 11, 45-49. [PubMed]

53. Gaut, J.P.; Liapis, H. Acute kidney injury pathology and pathophysiology: A retrospective review. Clin. Kidney J. 2020, 14, 526-536. [CrossRef] [PubMed]

54. Shi, J.; Qian, J.; Li, H.; Luo, H.; Luo, W.; Lin, Z. Renal tubular epithelial cells injury induced by mannitol and its potential mechanism. Ren. Fail. 2018, 40, 85-91. [CrossRef] [PubMed]

55. Dickenmann, M.; Oettl, T.; Mihatsch, M.J. Osmotic nephrosis: Acute kidney injury with accumulation of proximal tubular lysosomes due to administration of exogenous solutes. Am. J. Kidney Dis. 2008, 51, 491-503. [CrossRef] [PubMed]

56. Visweswaran, P.; Massin, E.K.; Dubose, T.D., Jr. Mannitol-induced acute renal failure. J. Am. Soc. Nephrol. 1997, 8, 1028-1033. [CrossRef] [PubMed]

57. Lin, S.Y.; Tang, S.C.; Tsai, L.K.; Yeh, S.J.; Shen, L.J.; Wu, F.L.; Jeng, J.S. Incidence and risk factors for acute kidney injury following mannitol infusion in patients with acute stroke: A retrospective cohort study. Medicine 2015, 94, e2032. [CrossRef] [PubMed] 
58. Asif, A.; Preston, R.A.; Roth, D. Radiocontrast-induced nephropathy. Am. J. Ther. 2003, 10, 137-147. [CrossRef] [PubMed]

59. Seeliger, E.; Lenhard, D.C.; Persson, P.B. Contrast media velocity versus osmolality in kidney injury: Lesson from animal studies. BioMed Res. Int. 2014, 2014, 358136. [CrossRef]

60. Lancelot, E.; Idee, J.P.; Lacledere, C.; Santus, R.; Corot, C. Effects of two dimetric iodinated contrast media on renal medullary blood perfusion and oxygenation in dogs. Invest. Radiol. 2002, 37, 368-375. [CrossRef]

61. Skrifvars, M.B.; Bailey, M.; Moore, E.; Martensson, J.; French, C.; Presneill, J.; Nichol, A.; Little, L.; Duranteau, J.; Huet, O.; et al. A post hoc analysis of osmotherapy use in the erythropoietin in traumatic brain injury study-Associations with acute kidney injury and mortality. Crit. Care Med. 2021, 49, e394-e403. [CrossRef]

62. Dorman, H.R.; Sondheimer, J.H.; Cadnapaphornchai, P. Mannitol-induced acute renal failure. Medicine 1990, 69, 153-159. [CrossRef]

63. Moustafa, H.; Schoene, D.; Altarsha, E.; Rahmig, J.; Schneider, H.; Pallesen, L.P.; Prakapenia, A.; Siepmann, T.; Barlinn, J.; Paussauer, J.; et al. Acute kidney injury in patients with malignant middle cerebral artery infarction undergoing hyperosmolar therapy with mannitol. J. Crit. Care 2021, 64, 22-28. [CrossRef]

64. Schmitt, J.; Rahman, A.F.; Ashraf, A. Concurrent diabetic ketoacidosis with hyperosmolality and/or severe hyperglycemia in youth with type 2 diabetes. Endocrinol. Diab. Metab. 2020, 3, e00160. [CrossRef] [PubMed]

65. Royal Australian College of General Practioners. General Practice Management of Type 2 Diabetes 2016-2018. Available online: www.racgp.org.au/clinical-resources/clinical-guidelines/key-racgp-guidelines/view-all-racgp-guidelines/managementof-type-2-diabetes (accessed on 5 May 2021).

66. Nomani, A.Z.; Nabi, Z.; Rashid, H.; Janjua, J.; Nomani, H.; Majeed, A.; Chaudry, S.R.; Mazhar, A.S. Osmotic nephrosis with mannitol: A review article. Ren. Fail. 2014, 36, 1169-1176. [CrossRef]

67. Kim, M.Y.; Park, J.H.; Kang, N.R.; Jang, H.R.; Lee, J.E.; Huh, W.; Kim, Y.G.; Kim, D.J.; Hong, S.C.; Kim, J.S.; et al. Intreased risk of acute kidney injury associated with higher infusion rate of mannitol in patients with intracranial haemorrhage. J. Neurosurg. 2014, 120, 1340-1348. [CrossRef] [PubMed]

68. Narayan, S.W.; Castelino, R.; Hammond, N.; Patanwala, A.E. Effect of mannitol plus hypertonic saline combination versus hypertonic saline monotherapy on acute kidney injury after traumatic brain injury. J. Crit. Care 2020, 57, 220-224. [CrossRef] [PubMed]

69. Gu, J.; Huang, H.; Huang, Y.; Sun, H.; Xu, H. Hypertonic saline or mannitol for treating elevated intracranial pressure in traumatic brain injury: A meta-analysis of randomized controlled trials. Neurosurg. Rev. 2019, 42, 499-509. [CrossRef]

70. Huang, X.; Yang, L.; Ye, J.; He, S.; Wang, B. Equimolar doses of hypertonic agents (saline or mannitol) in the treatment of intracranial hypertension after severe traumatic brain injury. Medicine 2020, 99, e22004. [CrossRef] [PubMed]

71. Shi, J.; Tan, L.; Ye, J.; Hu, L. Hypertonic saline and mannitol in patients with traumatic brain injury: A systematic and meta-analysis. Medicine 2020, 99, e21655. [CrossRef]

72. Patil, H.; Gupta, R. A comparative study of bolus dose of hypertonic saline, mannitol, and mannitol plus glycerol combination in patients with severe traumatic brain injury. World Neurosurg. 2019, 125, e221-e228. [CrossRef]

73. DeNett, T.; Feltner, C. Hypertonic saline versus mannitol for the treatment of increased intracranial pressure in traumatic brain injury. J. Am. Assoc. Nurse Pract. 2019, 33, 283-293. [CrossRef]

74. Wiorek, A.; Jaworski, T.; Krzych, Ł.J. Hyperosmolar threatment for patients at risk for increased intracranial pressure: A singlecenter cohort study. Int. J. Environ. Res. Public Health 2020, 17, 4573. [CrossRef]

75. Popovic, Z.V.; Embgenbroich, M.; Chessa, F.; Nordström, V.; Bonrouhy, M.; Hielscher, T.; Gretz, N.; Wang, S.; Mathow, D.; Quast, T.; et al. Hyperosmolarity impedes the cross-priming competence of dendric cells in a TRIF-dependent manner. Sci. Rep. 2017, 7, 311. [CrossRef] [PubMed]

76. Junger, W.T.; Hoyt, D.B.; Davis, R.E.; Herdon-Remelius, C.; Namiki, S.; Junger, H.; Loomis, W.; Altman, A. Hypertonicity regulates the function of human neutrophils by modulating chemoattractant receptor signalling and activating mitogen-activated protein kinase p38. J. Clin. Investig. 1998, 101, 2768-2779. [CrossRef]

77. Cvetkovic, L.; Perisic, S.; Titze, J.; Jäck, H.M.; Schuh, W. The impact of hyperosmolality on activation and differentiation of B lymphoid cells. Front. Immunol. 2019, 10, 808. [CrossRef] [PubMed]

78. Powers, K.A.; Zurawska, J.; Szaszi, K.; Khadaroo, R.G.; Kapus, A.; Rotstein, O.D. Hypertonic resuscitation of hemorrhagic shock prevents alveolar macrophage activation by preventing systemic oxidative stress due to gut ischemia/reperfusion. Surgery 2005, 137, 66-74. [CrossRef] [PubMed]

79. Wright, F.L.; Gamboni, F.; Moore, E.E.; Nydam, T.L.; Mitra, S.; Silliman, C.C.; Banerjee, A. Hyperosmolarity invokes distinct anti-inflammatory mechanisms in pulmonary epithelial cells: Evidence from signalling and transcription layers. PLoS ONE 2014, 9, e114129. [CrossRef]

80. Lopez-Rodríguez, C.; Aramburu, J.; Jin, L.; Rakeman, A.S.; Michino, M.; Rao, A. Bridging the NFAT and NF-кB families: NFAT5 dimerization regulates cytokine gene transcription in response to osmotic stress. Immunity 2001, 15, 47-58. [CrossRef]

81. Dong, Z.H.; Wang, D.C.; Liu, T.T.; Li, F.H.; Liu, R.L.; Wei, J.W.; Zhou, C.L. The roles of MAPKs in rabbit nucleus pulposus cell apoptosis induced by high osmolality. Eur. Rev. Med. Pharmacol. Sci. 2014, 18, 2835-2845.

82. Malek, A.M.; Goss, G.G.; Jiang, L.; Izumo, S.; Alper, S.L. Mannitol at clinical concentrations activated multiple signaling pathways and induces apoptosis in endothelial cells. Stroke 1998, 29, 2631-2640. [CrossRef] 
83. Schwartz, L.; Guais, A.; Pooya, M.; Abolhassani, M. Is inflammation a concequence of extracellular hyperosmolarity? J. Inflamm. 2009, 6, 21. [CrossRef] [PubMed]

84. Mitchell, N.C.; Gilman, T.L.; Daws, L.C.; Toney, G.M. High salt intake enhances swim stress-induced PVN vasopressin cell activation and active stress coping. Psychoneuroendocrinology 2018, 93, 29-38. [CrossRef]

85. Sailer, C.O.; Wiedemann, S.J.; Strauss, K.; Schnyder, I.; Fenske, W.K.; Christ-Crain, M. Markers of systemic inflammation in response to osmotic stimuli in healthy volunteers. Endocr. Connect. 2019, 8, 1282-1287. [CrossRef]

86. Ziegeler, S.; Raddatz, A.; Schneider, S.O.; Sandman, I.; Sasse, H.; Bauer, I.; Kubulus, D.; Mathes, A.; Lausberg, H.F.; Rensing, H. Effect of haemofiltration and mannitol treatment on cardiopulmonary-bypass induced immunosuppression. Scand. J. Immunol. 2009, 69, 234-241. [CrossRef] [PubMed]

87. Al-Sarraf, H.; Ghaaedi, F.; Redic, Z. Time course of hyperosmolar opening of the blood-brain and blood-CSF barriers in spontaneously hypertensive rats. J. Vasc. Res. 2007, 44, 99-109. [CrossRef]

88. Huang, K.; Zhou, L.; Alanis, K.; Hou, J.; Baker, L.A. Imaging effect of hyperosmolality on individual tricellular junctions. Chem. Sci. 2020, 11, 1307-1315. [CrossRef]

89. Burks, S.R.; Kersch, C.N.; Witko, J.A.; Pagel, M.A.; Sundby, M.; Muldoon, L.L.; Neuwelt, E.A.; Frank, J.A. Blood-brain barrier opening by intracarotid artery hyperosmolar mannitol induces sterile inflammatory and innate immune responses. Proc. Natl. Acad. Sci. USA 2021, 118, e2021915118. [CrossRef] [PubMed]

90. Stonestreet, B.S.; Sadowska, G.B.; Leeman, J.; Hanumara, R.C.; Petersson, K.H.; Patlak, C.S. Effects of acute hyperosmolality on blood-brain barrier function in ovine foetuses and lambs. Am. J. Physiol. Regul. Integr. Comp. Physiol. 2006, 291, R1031-R1039. [CrossRef]

91. Joshi, S.; Ellis, J.A.; Ornstein, E.; Bruce, J.N. Intraarterial drug delivery for glioblastoma multiforme: Will the phoenix rise again? J. Neurooncol. 2015, 124, 333-343. [CrossRef]

92. Fortin, D.; Desjardins, A.; Benko, A.; Niyonsega, T.; Boudrias, M. Enhanced chemotherapy delivery by intraarterial infusion and blood-brain barrier disruption in malignant brain tumors: The Sherbrooke experience. Cancer 2005, 103, 2606-2615. [CrossRef]

93. Marchi, N.; Betto, G.; Fazio, V.; Fan, Q.; Ghosh, C.; Machado, A.; Janigro, D. Blood-brain barrier damage and brain penetration of antiepileptic drugs: Role of serum proteins and brain edema. Epilepsia 2009, 50, 664-677. [CrossRef] [PubMed]

94. Godinho, B.M.D.C.; Henninger, N.; Bouley, J.; Alterman, J.F.; Haraszti, R.A.; Gilbert, J.W.; Sapp, E.; Coles, A.H.; Biscans, A.; Nikan, M.; et al. Transvascular delivery of hydrophobically modified siRNAs: Gene silencing in the rat brain upon disruption of the blood-brain barrier. Mol. Ther. 2018, 26, 2580-2591. [CrossRef] [PubMed]

95. Liu, A.H.; Chen, N.Y.; Tu, P.H.; Wu, C.T.; Chiu, S.C.; Huang, Y.C.; Lim, S.N.; Yip, P.K. DHA attenuates cerebral edema following traumatic brain injury via the reduction in blood-brain barrier permeability. Int. J. Mol. Sci. 2020, 21, 6291. [CrossRef] [PubMed] 